\title{
Integral Formation for the Engineering for Peace from a Systemic and Interdisciplinary Perspective
}

\author{
Luis Fernando Cruz Quiroga ${ }^{1,3}$ Joel Howell $^{2}$, Wilfrido Alejandro Moreno ${ }^{1,2,3}$ \\ ${ }^{I}$ Complex Systems \& Education Network - ISTEC (SCED-ISTEC) \\ ${ }^{2}$ University of South Florida(USF) - Electrical Engineering Department \\ ${ }^{3}$ Ibero-American Science and Technology Education Consortium (ISTEC)
}

\begin{abstract}
-
Purpose: the Electrical Engineering Department at the University of South Florida (USF), the Ibero-American Science \& Technology Education Consortium (ISTEC) and the Complex Systems and Education (SCED), under the R\&D ISTEC initiative, have developed a comprehensive electrical engineer formation model based on the Adaptive Complex Systems approach that responds to the challenges of the contemporary society (presented at WEEF 2012). The purpose of this paper is to show an application reference of the model in the development of ethical competences in the formation of the engineer for peace from a systemic and trans-disciplinary approach, integrating academia, industry and the community.

Method: a sequence of three progressive levels of one credithour courses for the Professional Formation of the Engineer (PRF) that integrate ethical competences focused on the being, the knowledge and the know-how. It includes individual and team work, resolution of case studies, simulations, ethics presentations, ethical practices, proposals writing, visits to industry and networking with successful industry professionals.

Results: graduates linked to the newly created True-Partner Network demonstrate their behavior integrity, responsibility, ability to interact respectfully with others and accepting differences in favor of general interests.

Conclusion: the ethical values of peace engineer must be formed through a systematic inter/multi/trans-disciplinary pedagogical approach connected to the labor sector throughout the Bachelor's program.
\end{abstract}

Keywords: employability, engineering, ethical, integral, peace, interdisciplinary

\section{INTRODUCTION}

The human being has to live in an ethically regulated society. To accomplish this, he/she must adapt and learn to live in peace and in harmony with others [1]. Therefore, ethics attempts to objectively measure the behavior of people and their effect on society [2]. In this sense, the importance of ethics in engineering is increasingly highlighted as a series of common criteria that clearly stipulate the obligations and responsibilities of engineers to face the working world in the contemporary society. The absence of an ethical culture in the engineer not only hinders their professional development, but also affects the closest people around them [3].

In order to optimize the ethical behavior, the different engineering societies such as the National Society of Professional Engineers (NSPE), the American Institute of Chemical Engineers (AIChE), the Institute of Electrical and Electronics Engineers (IEEE), the American Society of Civil Engineers (ASCE), the American Society of Mechanical Engineers (ASME) and the Accreditation Board for Engineering and Technology (ABET) have created codes of ethics that identify obligations, responsibilities, common criteria and standards of the engineer's professional conduct for the purpose to guide their behavior with integrity, honor and dignity in society [4].

However, in reality, codes of ethics remain theoretical and vague without practical application [4] since engineering ethics implies conviction [2], individual and collective commitment [5] and the development of complex cognitive processes within different contexts; therefore, it transcends the follow-up of a list of professional behaviors [5]. Although ethics deals with reasoning of why something seems right or wrong, why should I (or should not) do what I should (or not) do [6], "what is good for one person is not good for another" [7],[8],[9],[10].

In order to try to solve the basic problem from the formation of engineers perspective, ethics has being integrated, in a multidisciplinary approach, into engineering curriculums through humanistic and ethical content. However, the traditional teaching of engineering ethics does not fit the engineer's way of thinking and acting. Consequently, 
students consider ethics and humanities courses as subjects that are distant from their technological and scientific training [11 ] Engineering is a practical discipline that systematically applies solid technical and scientific principles to solve problems. Therefore, engineering ethics must be practical, applied and oriented towards individual behavior, technical professional (micro-ethics), and to the collective relations or social (macro-ethics) in order to preserve the common good and serve society [12], [13],[14].

Ethics is not in the manuals ... Ethics is learned in practice, in life and in relationships [15]. Ethics is not a moral state that can be conditioned a priori. It is not a virtue that can be taught or transmitted. It is a system or a complex behavior that emerges in the practical interaction of the student or the professional within an environment and with others, in a nonlinear way, in a particular moment and determined by a social-historical context, in constant adaptation and reconstruction. Therefore, to think of ethical formation as a series of ideal conditions, pre-determined, inherent to the human being, isolated from its context and from the other subjects, is to ignore the dynamics of reality [16]. From this perspective, the USF's Electrical Engineering Department and the SCED-ISTEC have developed a comprehensive engineer training model based on the Adaptive Complex Systems approach that responds to the challenges of contemporary society presented at WEEF 2012 [17]. The purpose of this paper is to show a reference of application of the model in the development of ethical competences in the formation of the engineer for peace from a systemic, interdisciplinary approach, integrating academia and industry.

\section{METHOD}

Implementation of a Professional Formation for Engineers (PFE) program with active educational experiences that integrate university, industry and society in a practical and systematical way. It takes place in sessions of one hour and fifty minutes per week for 16 weeks. Ethical training is carried out through collaborative learning that integrates the development of personal, technical and professional skills, stakeholder need analysis, society interests/trends, global thinking, exploration of job opportunities, research activities, and innovation \& entrepreneurial thinking. The objective of the course series is to develop the ethical training of students in a practical way in three progressive levels that integrate ethical competences in the being, the knowledge and the know-how in an adaptive way. The learning scenarios revolve around group discussions conducted mainly by the students and facilitated by the instructor. Pedagogical mediations include individual and team work, resolution of case studies, simulation practices, group discussions, ethics hearings, defense and criticism of ethical practices, development of practical proposals, visits to the external sector, contact with successful professionals of the industry, and interaction with industry labor networks. The scenarios and the strategies proposed allow for active learning with a permanent ethical reflection applied in different contexts.

The aim is that the students learn to develop ethical competences in engineering through active and collaborative instructional strategies and just not only to convey concepts and codes of ethics.

The development of competencies is a continuous process that is achieved through the PFE-1, PFE-2 and PFE-3 course sequence. The process offers continuous follow-up and permanent feedback by the instructor to each individual student based on the achievement indicators. Feedback implies an improvement plan carried out jointly with the student; i.e., the student identifies and actively participates in the enhancement process by proposing activities that help improve ethical competences while the instructor facilitates instruction tools and strategies according to the student's needs and the development level of the competencies.

Although the competencies are previously defined, the system is flexible and adaptable. Other competences to be developed may arise during the process which then will be defined jointly.

\section{Achievement indicators}

- The student works in disciplinary teams

- The student works in interdisciplinary teams

- The student listens actively

- The student communicates assertively

- The student communicates verbally and nonverbally in a friendly and respectful way

- The student develops empathy with the working team members

- The student respects the opinions of peers and the instructor

- The student attends promptly to the various proposed activities (classroom, laboratories, industry, committees etc.)

- The student debates argumentatively with respect

- The student reaches consensus

- The student recognizes classmates' achievements and successes

- The student reflects and discusses on the pros and the cons of ethical behaviors at the different stages of the formation in engineering (laboratories, lectures, classroom, industry, committees, projects etc.)

- The student directs discussions and debates

- Student responsibly comply with agreements and agreed obligations

- The student accepts suggestions for behavior change given by peers and the instructor.

- The student adapts to different stages of learning and duties

- The student proposes solutions (strategies and activities) to difficulties detected in his/her behavior

- The student changes his/her behavior in different scenarios of training in engineering (classroom, laboratories, industry, committees, projects etc.)

Indicators for each competence are determined in three levels of achievement: 1 high level, 2 middle level, and 3 low level. 
Each level is evaluated qualitatively and quantitatively. At the qualitative level, the factors that hinder the attainment of the competence are specified and at the quantitative level, the evaluation is concurrently carryout with the following score: 1. high level (A, 80-100), indicates that it has developed the competence; 2 . middle level (B, 60-80), indicates that it has partially developed the competence and 3. low-level $(\mathrm{C}$, below 60), indicates that it has no developed the competence. The instructor identifies during the first course the level of achievement of the competences and the difficulties that limit their development and from the outset the instructor generates joint strategies with students to develop the competences through the three courses. If by the end of the third course, the student has not achieved a high level the student must repeat the course until the development of competence.

The development of ethical competences with active participation and empowerment of the students is part of the Electrical Engineering Department's TRUE philosophy "Taking Responsibility to Understand Engineering. The TRUE aims to change the way in which individuals, organizations and systems relate to each other and work together. It is based on the idea that the responsibility and the student's formation is not exclusive of an individual in particular. It is a responsibility shared and distributed. It implies active empowerment from the academic community and industry in order to have impact.

The TRUE-Initiative has been integrated in the different processes within the curriculum of the Electrical Engineering Department, see figure 1. In addition, a newly created network of industrial partners: The TRUE-Partner Network with active participation of students and professors has been created. In this context, the ethical formation is transversal and essential.

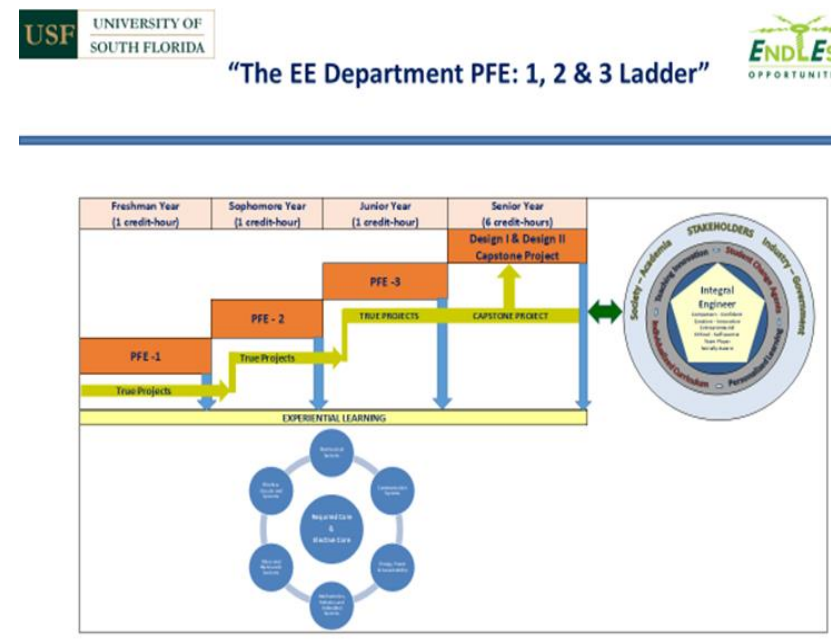

Fig 1. The EE department PFE 1, 2, \& 3 Ladder

\section{RESULTS}

Graduates linked to the True-Partner Network demonstrating in their behavior integrity, responsibility, ability to interact respectfully with other people, accepting differences in favor of general interests.

The courses Professional Formation of Engineers (PFE) 1, 2, and 3 have connected the freshman engineering experience to the senior capstone design course by weaving professional skills and competencies (see Career Readiness at National Association of Colleges and Employers http://www.naceweb.org/career- adiness/competencies/careerreadiness-defined/) through the students' sophomore and junior years. A key characteristic of the PFE is that it has allowed for an active and a collaborative engagement of students with industry professionals and experiential learning activities beyond the university environment (service projects, community engagement, internships etc.) The course activities have included among others career planning, development and completion of a personalized qualification plan based on each student's professional goals, innovative design, project management, professional ethics, and entrepreneurship. Students in the inaugural class (PFE 1) identified a high impact project - a sustainable "Container Farm" and several teams (equivalent to a real company) were created for the development and prototyping of the farm. At the senior level, the BSEE program curriculum continues to strengthen community ties through the TRUE Partner Network.

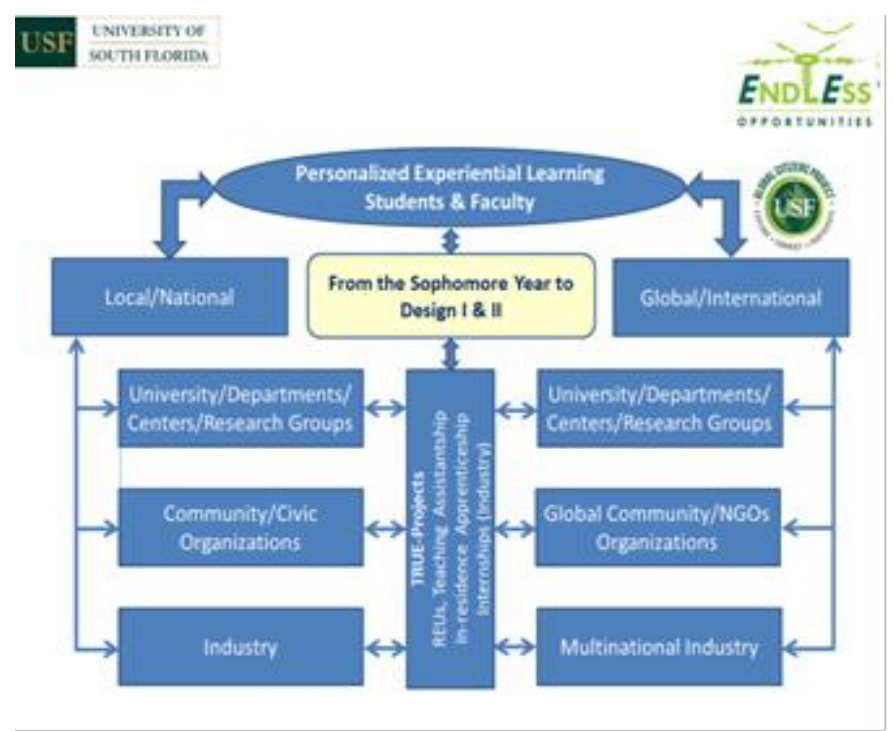

Fig 2. Personalized Experiential Learning Overview

The TRUE-Partner is a network of local and regional companies that team with the Electrical Engineering Department to define industry based projects for the senior capstone design effort. A meeting of the participating companies was held on July 2017 with participation of the following companies: Manitowoc/Welbilt, Florida Power \& Light, RCA Solutions, DeliverLogic, NREC, GE Instrument Transformers, and Withlacoochee River Electric Cooperative, Inc. In the first year, nearly 20 BSEE graduates have participated in industry driven projects defined by the TRUEPartner Network. 


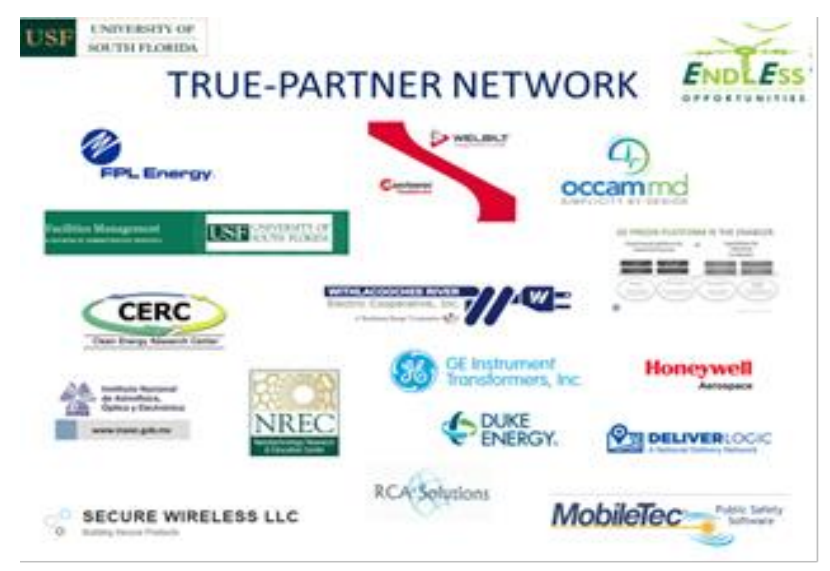

Fig 3. TRUE-Partner Network participating entities

\section{IV.CONCLUSIONS}

The ethical training of an engineer for peace must be carried out through a systemic, complex and adaptive interdisciplinary pedagogical approach.

The ethical training of the peaceful engineer must be connected to the labor world, industry and society from the early stages and through the Bachelor's program.

Ethical education for peace is not taught through the transmission of humanistic or ethical content. It requires the design of practical and contextualized teaching-learning scenarios.

Ethical training for peace requires trained professors and wellmediated pedagogical processes.

\section{REFERENCES}

[1] Camps, V. (2009). Perspectivas éticas generales. In U. A. d. Barcelona (Ed.), Cuestiones éticas en ciencia y tecnología en el siglo XX. España: Biblioteca Nueva. Retrieved from

[2] Van de Poel; Royakkers, L. (2011). Normative Ethics. In WileyBlackwell (Ed.), Ethics, Technology, and Engineering: An Introduction: Wiley-Blackwell.

[3] Garcia, J. D. (2015). La ética en la profesión de ingeniería. La ética en la profesión de ingeniería ACIEM, 123-2.

[4] Harris,Ch, et al (2018) Engineering Ethics. Sixth Edition.

[5] Sánchez, B. J. (2005). Ética profesional Humanidades: la ética en el inicio del siglo XXI.

[6] Larios Risco, D. (2014). Ética y Administración Sanitaria. In Dykinson (Ed.), Ética y medicina. Madrid España: Dykinson

[7] Poel, I. v. d. R., Lamber. (2011). Ethics, Technology, and Engineering: An Introduction. [book]. 376.

[8] Naagarazan, R. S. (2006). Textbook on professional ethics and human values, from http://public.eblib.com/choice/publicfullrecord.aspx? $\mathrm{p}=351920$ [9] Blackburn, S. (2003). Ethics: A Very Short Introduction. Oxford: Oxford University Press.

[10] Martin, M. W. S., Roland. (2000). Ethics and professionalism. In D. B. Hash (Ed.), Introduction to engineering ethics (Second ed., pp. 8). Boston: McGraw-Hill Higher Education.

[11] Chávez E, Cuauhtémoc S (2014) Ética para ingenieros. Grupo editorial Patria, México

[12] Ladd, J. (1985). The quest for a code of professional ethics: an intellectual and moral confusion. In G. J. Deborah \& W. S. John (Eds.), Ethical issues in the use of computers (pp. 8-13): Wadsworth Publ. Co.

[13] Herkert, J. R. (2001). Future directions in engineering ethics research: Microethics, macroethics and the role of professional societies. [journal article]. Science and Engineering Ethics, 7(3), 403-414. doi: 10.1007/s11948-001-0062-2
[14] McLean, G. F. (1993). Integrating ethics and design. IEEE Technology and Society Magazine, 12(3), 19. doi: 10.1109/MTAS.1993.232282

[15]Kisnerman, N. (2001). "Ética, ipara qué?". En N. Kisnerman (Compilador), I. Aguirre, E. Balestena, J. García y J. Hernández: Ética ¿Un discurso o una práctica social? (107-121). Buenos Aires: Paidós Ibérica.

[16] Cruz Luis. F (2018) Humanismo en Educación: proceso emergente de un Sistema Complejo Adaptativo en Presente y futuro de las humanidades. Editorial Universidad de San Buenaventura.

[17] Cruz Luis. F Moreno W (2012) "Curricular Development for Engineering Education to meet the challenges of the XXI Century from a Complexity Perspective". SCED-ISTEC@ University of South Florida USF. World Education Engineering Forum 2012 (WEEF). American Society for Engineering Education ASEE. edUtecNe - EDITORIAL DE LA UNIVERSIDAD TECNOLÓGICA NACIONAL. Buenos Aires Argentina. 